\title{
Bartın Nehri Gölbucağı-Boğaz Kesimi Rekreasyonel Kullanım Amaçlı Peyzaj Tasarım Projesi
}

\author{
Nurhan KOÇAN ${ }^{1^{*}}$, Nüket ANKARALI ${ }^{2}$
}

\begin{abstract}
Öz
İnsanoğlu yaşam sürecinin başından itibaren suya çeşitli nedenlerle ihtiyaç duymuş ve yerleşim amaçlı ilk tercihlerini su kaynaklarına yakın alanlarda yapmıştır. Değişik nitelik ve boyutlarda olan bu istek ve ihtiyacı karşılayabilecek kaynak ve alanlar ise dünyanın farklı yerleşim alanlarında ve kültürlerinde geniş bir yelpaze içesinde bulunmaktadır. Su kaynakları rekreasyon amacı için de peyzaj mimarlığı disiplinin ayrı bir çalışma konusu olmuştur. Ekolojik planlamalar yanı sıra kaynakların etkin ve verimli kullanımını sağlayacak peyzaj planlama ve tasarım ilkeleri bu alanlar için önemli temel teşkil etmektedir. Akarsu ve nehir kenarı peyzaj planlama ve tasarım ilkeleri aracılığı ile ekolojik ve mekânsal anlamda daha kaliteli mekanlar yaratılacağı bir gerçektir. Çalışmada dünya ve ülkemiz örneğinde farklı akarsu ve nehir kaynaklarının planlama ve tasarımına yönelik araştırmalar yapılmıştır. Araştırmalardan elde edilen bilgilerin analizi sonucunda Bartın Nehri Gölbucağı Boğaz Kesimi için rekreasyonel alan kullanım planlamasına yönelik değerlendirmeler yapılmış ve alanın peyzaj tasarım projesi çizilmiştir. AutoCad2014, Photoshop CS5, Sketchup ve Lumion yazılımları projelerin çizimi, üç boyutlu gösterimleri ve sunumu aşamalarında kullanılmıştır. Üretilen sonuç projenin ülkemiz ve dünya kentlerindeki nehir kenarı düzenleme çalışmalarına fikir vereceği düşünülmektedir.
\end{abstract}

Anahtar Kelimeler: Akarsu, rekreasyon, peyzaj tasarımı, Bartın.

\section{Landscape Design Project of Gölbucagı-Bogaz District of Bartın River for Recreational Use}

\begin{abstract}
From the beginning of human life, people have needed water for various reasons and they have made their first preference in order to settle in areas close to water resources. The resources and areas that can meet this desire and need in different qualities and dimensions, are in a wide range for different settlement areas and cultures of the world. Water resources have also been a separate study topic within the landscape architecture discipline for the recreational purpose. Landscape planning and design principles that will provide effective and efficient use of resources and ecological planning are important task for these areas. It is a fact that rivers will create better quality spaces in ecological and spatial point through landscape planning and design principles. In this study different river resources in our world and our country have been evaluated based on the planning and design principles. As a result of the analysis of the information obtained from the researches, evaluations were made for recreational area usage planning for the Gölbucağı Boğaz District of Bartın River and the landscape design project of the area was drawn. The AutoCad2014, Photoshop CS5, Sketchup and Lumion software were referred used for drawing and 3D presentation phases of the projects. It is thought that the result of the project will give an idea about the river side regulation works for our country and world cities.
\end{abstract}

Keywords: River, recreation, landscape architecture, Bartın.

${ }^{1}$ Bartın Üniversitesi Müh. Mimarlık ve Tasarım Fakültesi, Peyzaj Mimarlığı Bölümü, Bartın, Türkiye, nkocan@bartin.edu.tr
${ }^{2}$ Bartın Üniversitesi Müh. Mimarlık ve Tasarım Fakültesi, Peyzaj Mimarlığı Bölümü, Bartın, Türkiye, nurhankocan@yahoo.com.tr

${ }^{1}$ https://orcid.org/0000-0001-9433-7007 ${ }^{2}$ https://orcid.org/0000-0001-9433-7008 


\section{Giriş}

Akarsular ekolojik ve ekonomik anlamda değerli doğal kaynaklardır. Bu nedenle yüzlerce yıldır çeşitli amaçlarla kullanılmışlardır. Bu kaynaktan ekolojik değerlerine zarar vermeden yararlanmak öncelikli amaçtır. Özellikle son yıllarda kent yaşamında doğadan kopan kentliler için böyle bir kaynağın varlığ 1 yeni ekonomik ve ticari olanakları beraberinde getirecektir. Bu nedenle bu alanların doğru şekilde planlanıp tasarlanması ve bu planlama ve tasarımlarda kamu yararının gözetilmesi esas olması gerekmektedir (Önen, 2006).

$\mathrm{Bu}$ çalışma örnek bir çalışma niteliğinde olup diğer illerde de uygulanabilecek yapıdadır. $\mathrm{Bu}$ tür çalışmaların, ülke genelinde yaygınlaşması kentleri dünya ülkeleri ile rekabet edecek seviyeye yükseltecektir. Böylece ülkelerin sosyal, kültürel ve ekonomik olarak gelişmesinde ve aynı zamanda halkın yaşam kalitesinin ve refahının yükseltilmesinde etkin bir rol oynayan doğal alan ve kaynakların devamlılığı sağlanabilecektir. Kent içindeki konumu ve kent merkezine yakınlığı ile çalışma alanının rekreasyonel amaçlarla yeniden düzenlenmesi daha kaliteli bir mekân oluşumunu sağlayacak, alanın etkin ve verimli kullanımını artıracaktır. Bireylerin doğanın kaynaklarını yakından tanıması ve değerlendirmesi, bu ortamlarda yapılacak yeni yatırımları, yeni iş ve ekonomik getirileri teşvik edecektir. Yurt içinde ve yurt dışında yapılan incelemeler projenin bu yöndeki sonucu olabileceğini göstermektedir.

\subsection{Su - Çevre - İnsan İlişkileri}

Su kaynakları insan ve çevre üzerinde fiziksel ve psikolojik yönden olumlu etki yaratır. Bunlar mekânı zenginleştirerek insanlar için kaliteli ortamlar oluşturur. Planlama çalışmalarında suyun bu etkilerine ek olarak yapılacak bitkisel ve yapısal tasarımlarla mekânın özellikleri zenginleştirilebilir (Hattapoğlu, 2004). Su ögesi peyzajdaki en ilginç obje olup insanı cezbeder. Su boşluğun sıkıcılığını ve monotonluğunu kırar, manzarayı zenginleştirir (Fairbrother, 1976). Kent içinde yer alan su elemanları kent kimliğini şekillendirir. Kentsel doğal su elemanlarının kent için öneminin ve suyun mekân tasarımlarına kattığı gücün değerinin anlaşılmasıyla günümüzde farkındalığı artmıştır (Önen, 2006).

Kentlerdeki su kaynaklarının korunması ve geliştirilmesi doğal alanlara göre daha zordur. Kent yaşamının su kaynaklarına verdiği zararlı etkiler kısa zamanda ortaya çıkmakta ve bu etkilerin bertaraf edilmesi uzun zaman almaktadır. Kentsel su kaynakları halkla çok yakın ilişkide olduğu için suyun görsel ve sağlık özellikleri bakımından daha fazla kontrolü gerekir. Kent içindeki doğal su ögeleri doğru bir şekilde analiz edilerek tasarlanmalıdır (Önen, 2006). 
Kentlerde yaşam standartları değiştikçe rekreasyon ihtiyacı olağan bir gereksinime dönüşmüştür. Son yıllarda kıyılarda rekreasyon amaçlı düzenlemelere yer verilmektedir. Âtıl durumda olan veya kirlenen su ve kıyıların kente kazandırılması için alternatif çalışmalar yapılmaya başlanmıştır (Berberoglu, 2004). Akarsu kıyıları da bu çalışmaların yapıldı̆̆ı yerler arasındadır. Doğal yaşam çeşitliliğinin en fazla olduğu yerler olarak akarsu kıyı kullanımının bir sistem ve yönetim altına alınması zorunlu bir önceliktir (Uzun, 2001).

\subsection{Akarsu Kıyı Kullanımları}

İlk çağlardan günümüze kadar yok olmadan gelebilen çekirdek yerleşimlerin çoğu akarsu kenarlarında kurulmuştur. İnsanlar verimliliği tükenen toprakları bırakıp gereksinimlerine yanıt verecek yeni su kenarlarına ulaşmaya çalışmışlardır. Akarsuyun hareket, beslenme ve ulaşımda verdiği kolaylıkların yani ekonomik potansiyel gücünün kullanılması onu önemli yapmıştır (An, 1994).

Kentleri ekolojik ağ gibi saran akarsuların, planlanan alan kullanım şekline uygun olarak ekolojik, rekreasyonel, kültürel açılardan tasarım ve yönetim sistemine dahil edilmesi gerekir. Çizgisel açık mekanlar olan akarsu kıyılarındaki çevre kalitesinin artırılması fiziksel planlamanın ön şartıdır (Ramos ve Aguilo, 1988; Kılıçaslan, 2004).

Akarsu kıyıları ve çevresinde sanayi tesislerinin ve konutsal yapılaşmaların kontrolsüz gelişimi, bu alanların zarar görmesine veya yok olmasına neden olmaktadır. Ruhsatsız yapılaşma, yanlış imar uygulamaları; akarsu yataklarına çöp ve kanalizasyon bırakılması, köprü ve menfezin gerekli standartlara sahip olmaması; akarsu çevresindeki doğal bitki örtüsünün tahrip edilmesi akarsuların insan kullanımlarına bağlı taşma nedenleri olarak bilinmektedir (Kılıçaslan, 2004).

$\mathrm{Su}$ kaynaklarının geliştirilmesi konusunda yapılan çalışmalar karmaşık, maliyetli ve çok aşamalıdır. Kent içinden geçen mevcut akarsu yatağı ve kıyı stabilizasyonunun yapılması, temizlenmesi sonucunda bir dizi peyzaj düzenleme çalışmalarının yapılması su kaynaklarının geliştirilmesi konusu içerisindedir. Su kaynakları geliştirilirken ekosistemlerin korunmasına öncelik verilmesi önerilmektedir. Akarsuların ıslah çalışmaları ile akarsular ve çevreleri daha yaşanabilir kaliteli alanlara dönüşebilecektir (Kılıçaslan, 2004).

Akarsu ve akarsu kıyıları farklı kotlara sahip olduğu için farklı rekreasyonel kullanım alanları oluşturulabilmektedir. Bunlar; yürüyüş ve gezinti yolları, doğal küçük parklar, piknik alanları, seyir terasları, balık avlama, kayık-yelken-kano-tekne gezintileri, restaurant, kafeterya vb. etkinlik ve mekanlar olabilir. Kıyılarda rekreasyon amaçlı kullanımlarda ulaşım; yine rekreasyon amaçlı oluşturulan akarsu ve denizlerde gezinti araçları ve kıyısal yapılar yürüyüş ve bisiklet yolları paten alanları vb. destekleyici yollar ile sağlanmaktadır. Rekreasyonel amaçlı kıyı ulaşım alanları kent ve 
kentliye yarar sağlayan kullanımlardır. Su kıyıları eğitim ve kültürel amaçlı kullanımlar için uygun alanlardır. Özellikle kültürel etkinlik ve düzenlemeler gezerken öğrenmenin en ideal yoludur. Kentlerde rekreasyonel kıyı kullanımları kentlilerin en çok tercih ettiği kullanımlardır (Simsonds, 1994). Akarsu kıyıları kent için ekolojik sürekliliğin sağlandığı doğal kaynak alanlarıdır. Aynı zamanda halkın kullanım sürekliliğinin olduğu alanlardır. Bu alanların peyzaj planlama ve tasarım ve çalışmalarındaki önemi büyüktür (Arslan ve ark., 2005).

\subsection{Akarsu Kıyısı Rekreasyonel Düzenleme İlkeleri}

Akarsular kamusal, lineer, açık yeşil alanlar olmaları açısından rekreasyon kullanımları için uygun mekanlardır. Bu alanlarda su ve kara kullanım potansiyeli yüksek olduğu için sosyal ve ekolojik ihtiyaçlar doğrultusunda fiziksel düzenlemeler ile şekillenebilirler. Bu alanlarda halkın, sosyal, kültürel, ekonomik yapısı ve ihtiyaçları doğrultusunda rekreasyonel düzenlemeler yapılabilir. Bir kıyı alanı peyzaj planlaması olarak akarsuları ele aldığımızda lineer konumda düşünülebilecek, göz önünde bulundurulması gereken beş dokusal şerit ortaya çıkmaktadır. Bu şeritler, su ögesi, peyzaj dokusu ve kent dokusudur (Şengül, 1995).

Akarsuların taşkın riski taşıdığı alanlarda yapılacak düzenlemelerde taşkın kontrolüne dikkat etmek gerekir. Getirilecek işlevler bu riske uygun seçilmelidir. Akarsu kıyısı düzenlemeleri bu alanların taşkın durumundaki hali ve normal halini göz önünde bulundurup her iki kullanıma da uygun olabilecek fonksiyonlara yönelik tasarlanmalıdır. Kara ve su arasındaki ilişki topografik yapı (kıyı ve akarsu yatağının fiziksel durumu) ve doğa şartları (akarsu rejimi, taşkın durumu) bakımından ne kadar çeşitli olsa da, akarsu kıyı düzenlemelerinde kent, su, kıyı ve bu yapıların sahip oldukları özelliklere göre yapılacak düzenlemelerle akarsular şekillenecektir.

Akarsu kıyı alanlarının planlamasında koruma-kullanma sağlanarak sürdürülebilir kalkınma politikası hedef alınmalı, kıyı mekanının düzenlemesinde; gelişime açık, esnek, uygulamaya yönelik çözüm ortaya konulmalı ve mevcut planlama kararları yasalara uyum sağlayabilmelidir. Kıyı planlamasında insan ölçeğinin sağlanması, topoğrafik düzenlemelerin yapılması, tasarlanan alanlarda estetik çekim gücünün yaratılması, alana kimlik kazandırılması, kullanışı ve emniyetli tasarım çözümleri getirilmesine dikkat edilmelidir (Musayev, 2003).

$\mathrm{Bu}$ bağlamda donatı elemanları ile desteklenecek ve peyzaj dokusu kesimine getirilebilecek akarsu kıyısı fonksiyon alanları; akarsu kıyısına paralel gezi yolu, üstü açık ve kapalı dinlenme alanları, otopark alanları, çocuk oyun alanları, spor alanları, meydanlar, pasif yeşil alanlar, sergi-satış birimleri, kafeler, çay bahçeleri, iskele alanları, bisiklet park alanları, paten ve koşu yolu, akarsu seyir basamak ve terasları, yaya ve yaya-araç köprüleri, diğer akarsu üstü geçiş alanları, görsel su ve 1şık öğelerini içeren mekanlar, ekolojik alanlar olabilir. 
Alana getirilecek fonksiyonların yer seçimi de önemlidir. Kullanıcıların akarsu ile bütünleşmesini sağlayacak öncelikler sağlanmalıdır. Manzaraya hâkim noktalarda, seyir terasları, iskele, yürüyüş yolu, bisiklet yolu, dinleme alanları, çay bahçeleri, kafe, restoran gibi fonksiyonlar getirilebilir. Kıyı çevresinde spor alanı, otopark alanı gibi daha fazla gürültü ve toz çıkarabilecek fonksiyonlara yer verilmelidir (Şişman ve Yetim, 2004)

Akarsuyu kenarlarında suya ve neme dayanıklı bitkiler seçilmelidir. Kıyı kenarında toprak kaymasını önlemek için toprak tutucu, zemini güçlendirici ve taşkına dayanıklı bitkiler dikilir. Bitkisel eleman seçimi bölgenin iklimi, topoğrafyası, afet riski, vejetasyon yapısı gibi özelliklerle değişebilir. Kıyılarda oluşturulabilecek yeşil alanlar kadar, bitkilendirmenin mümkün olmadığ alanlarda zemin üzerine yerleştirilecek bitki kasaları ile de bitkisel tasarım sağlanabilir. Kıyının su ile buluşma şekli ve alanın genişliği bitkisel donatının yerleştirilmesine yön verecek ayrı bir durumdur.

\section{Materyal ve Metot}

\subsection{Alana ait doğal ve kültürel verilerin tespiti}

Çalışma alanına farklı aylarda gidilerek sörvey çalışması yapılmıştır. Böylece farklı mevsim ve ay olmak üzere günün farklı zaman dilimlerinde alanın kullanıcılar yönünden nasıl tercih edildiği, alan bütünü dahilinde hangi aktivitelerin yapıldı̆̆ı, alanın en fazla tercih edilen ve en âtıl kalan bölümlerinin tespiti yapılmıştır. Yapılan gözlem ve değerlendirmelerle elde edilen tespit sonuçları fotoğraflarla kayıt altına alınmış ve vaziyet planı üzerine işlenmiştir. Diğer yandan alanın doğal ve kültürel verilerine yönelik literatür taraması yapılmış, çeşitli kurum ve kuruluşlardan elde edilen bilgiler bilgisayar ortamına aktarılmıştır.

\subsection{Alanın mevcut kullanımlarının tespiti}

Çalışma alanında güncel durumda kayıkla gezinti, olta balıkçılığı, piknik, araçla gezinti, sülün yetiştirme ve izleme, doğa gözlem ve dinlenme amaçlı aktiviteler kontrolsüz ve düzensiz bir şekilde yapılmaktadır. Alan çevresinde birkaç adet terk edilmiş boş restoran bulunmaktadır. Kayıkla gezinti için ise halkın kendi imkanları ile yaptı̆̆ı basit, derme çatma iskele benzeri yapılar bulunmaktadır. Bunun yanında nehir kenarının her iki yanında cep şeklinde durak noktası olabilecek boşluklar tespit edilmiştir. Eski Bartın-İnkum karayolu kalıntısının ise bazı bölümlerde oluşan çökmeler dışında alanın gezinti, yaya yolu veya bisiklet yolu şeklinde kullanılabileceği düşünülmektedir. Yine alan çevresinde yer alan işlevini kısmen veya tamamen yitiren endüstri ve sanayi alan ve yapılarının park 
alanı veya kamusal hizmet binası olarak kullanılmasının alanın kullanılabilirlik ve dolayısıyla tanınırlık düzeyini artıracağı düşünülmektedir.

\subsection{Rekreasyonel plan kararlarının oluşturulması}

Örnek alanlara bakıldığında genellikle oturma, dinlenme, yürüyüş yapma, bisiklete binme, doğa gözlem ve izlem, sportif balıkçılık, tekne ve kayıkla gezinti, yeme-içme, yüzme, piknik ve kamp yapma, fotoğraf çekme gibi aktivitelerin yapıldığı görülmüştür. En çok tercih edilen kullanımlar olması ve nehir ve çevresine minimum zarar vermesi sebebiyle çalışmamızda benzer aktiviteler yer alacaktır.

\section{4 İlgili yabancı literatürün taranması}

Çalışmada bir yandan arazi gözlemleri, mevcut durum tespiti ve örnek alan izlemleri yapılmasının yanı sıra ilgili yabancı literatür taraması ile çalışmanın temel kısmı oluşturulmaya başlanmıştır.

Arazi çalışmalarında tespit edilen altlıkların AutoCad 2016 yazılımı ile bilgisayar ortamına aktarılması ve peyzaj tasarım projesinin çizilmesi:

Bartın Belediyesi’nden temin edilen 1:5000 Nazım İmar Planı üzerinden çalışma alanı sınırları çıkarılmış ve altlık bilgisayar ortamına aktarılmıştır. Mevcut durum tespiti bu harita üzerinde işlenmeye başlamıştır. Altlık harita daha sonraki aşamada tasarım ölçeğinde alana yönelik tasarımların gösterilmesinde kullanılmıştır. Daha sonra tüm veriler ışığında çalışma alanına ait rekreasyonel peyzaj tasarım projesi geliştirilmiştir. Projelerin çizimi, görselleştirilmesi ve sunumunda AutoCad 2016, Photoshop CS5, Sketchup ve Lumion yazılımları kullanılmıştır.

\section{Bulgular ve Tartışma}

\subsection{Alanın Doğal Peyzaj Özellikleri}

Çalışma alanı Batı Karadeniz Bölgesi'nde Bartın Çayı Havzası'nda ve Bartın İli sınırları

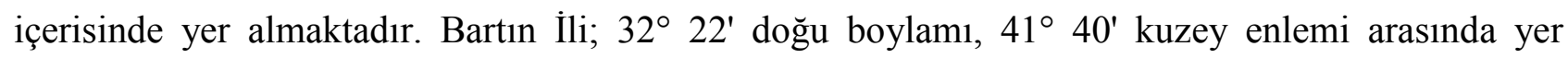
almaktadır. İlin yüzölçümü $2143 \mathrm{~km}^{2}$ dir. Bartın İli doğuda Kastamonu, güneyde Karabük, batıda Zonguldak illeri ile kuzeyde Karadeniz ile komşudur. Bartın İli’nin idari sınırları içerisinde; Merkez, Amasra, Kurucaşile ve Ulus olmak üzere dört ilçe yer almaktadır. Merkez İlçeye ait Arıt ve Kozcağız Beldeleri, Ulus İlçesine ait Kumluca Beldesi bulunmaktadır (Anonim, 1998). 
Bartın Çayı Havzası, tamamen Karadeniz'in deniz iklimi etkisi altındadır. Havzada hemen hemen her mevsim yağışlı ve 1lıman bir iklim karakteri egemendir. Karadeniz Bölgesi’nde yer alan Bartın'da tipik deniz iklimi hakimdir. Yazlar serin, kışlar 1lık ve yağışlı geçer. Yağışlar yazları yağmur, kışları yağmur ve kar şeklindedir. Bartın' da yıllık ortalama sıcaklık ise $12.5^{\circ} \mathrm{C}$ 'dir. Bartın'da yaz günleri sayısı yıllık 101.3 gündür. Yıllık ortalama yağış 1030 mm.dir. Bartın’da ortalama kar yağışlı günler sayısı yıllık 19.3 gündür. Bartın'da yıllık ortalama bağıl nem \%78'dir. Bartın Meteoroloji İstasyonuna göre ortalama rüzgâr hızı yıllık saniyede 1.4 m'dir (Anonim, 2006).

\subsubsection{Bitki Örtüsü}

Bartın Çayı ve kollarının boyunca yer alan düz alanlar, genellikle kentin tarım alanlarını oluşturmaktadır. Kent içi ve yakın çevresindeki tarım alanlarının akarsuya yakın olan kısımlarında, kavak ve fındık plantasyonları yoğunlaşmaktadır. Akarsuyun kent içi geçişinde, yatağın her iki tarafındaki şev alanları birkaç sıra ağaç örtüsü ile kaplanmış durumdadır. Bartın Çayı akarsu ve kıyı zonu bitkileri şunlardır: Salix alba (Ak Söğüt), Populus nigra (Kara kavak), Robinia pseudoacacia L. (Yalancı akasya), Platanus orientalis L. (Doğu çınarı), Ailanthus altissima L. (Kokarağaç), Fraxinus angustifolia subsp. oxycarpa (Sivri meyvalı dişbudak), Alnus glutinosa L. (Yaygın kızılağaç), Juglans regia L. (Ceviz), Ficus carica L. (İncir), Cornus sanguinea (Kızılcık), Rubus sanctus (Bögürtlen) şeklindedir. Salix alba L. (Ak söğüt) ve Populus nigra L. (Kara kavak) ise dominant türlerdir (Y1lmaz, 2001).

\subsubsection{Hidroloji}

Turoğlu ve Özdemir (2005)'e göre Bartın Çayı havzası, 8 alt havzadan oluşan, toplam 2059,35 km2’lik drenaj alanına sahiptir. Bartın Çayı alt havzasında, Abdipaşa'da Ulus kolu ile birleşen Gökırmak, Arıt Çayı ve Kozcağız deresi gibi önemli kolları ile Bartın Çayı'nın taşkın ovasında birleşirler. Böylece, Bartın kentinin de içinde bulunduğu taşkın ovasında, bir anda çok fazla su kütlesinin birleşme yeridir (Turoğlu ve Özdemir, 2005).

Bartın Çayı'nın bir kolu Kastamonu İli’nin Ulus İlçesi’ne bağlı köylerden doğar. Bu kol Ulus İlçesi'nin Şeyhler Köyü civarında Eflani’den gelen kolla, daha sonra da Amasra İlçesi'nin Yukarısal Köyü'nde doğan kolla birleşip il merkezine girer. Çay’ın diğer kolu ise, Hasankadı Beldesi’nden doğup, Ulus İlçesi’nin Hisar Köyü’nden doğan kolla Kozcağız Beldesi'nin Bakioğlu Köyü yakınlarından birleşip Bartın'a kadar gelir. Bu iki ana kol ise kent merkezinde Gazhane Burnu'nda birleşerek "Bartın Çayı” adını alır (Anonim, 2005). Bartın Çayı düzlük alanda menderesler çizdikten sonra Mollaosman ve Çaltalık sırtı mevkiler arasında sürempoze (epijenik) bir boğaz oluşturmaktadır. 
Boğaz Mahallesi'nden sonra oluşturduğu boğazdan çıkmakta Kurtluca Koyu'nda Karadeniz'e dökülmektedir (Demirca, 1999).

Bartın Çayı, Karadeniz’e ulaşana kadar kat ettiği 12 km boyunca derin bir yatak içinde çok yavaş olarak akmaktadır. Akış hızı saatte $720 \mathrm{~m}$ olup, her yıl denize 1 milyar $\mathrm{m}^{3}$ su akıtmaktadır. Bu özelliği ile Bartın Çayı, üzerinde su yolu taşımacılığına elverişli olup, ülkemiz akarsuları içerisinde önemli bir yere sahiptir. Bartın Çayı'nda 1950'li yıllarda 500 tonluk gemilerle Karadeniz'den Bartın kent merkezine kadar (Yalı İskelesi) ulaşım yapılabilmiştir (Anonim, 1995). Ancak günümüzde doğal süreçler ve insan müdahalesi sonucunda akarsu yatağında meydana gelen değişimler sonucunda sadece küçük tonajlı teknelerle Karadeniz'den kent merkezinde Yalı Mevkii'nde bulunan tarihi iskeleye ulaşılabilmektedir. Daha küçük tonajlı tekneler vasıtasıyla Bartın Çayı'nın kent içi kolları üzerinde ulaşım yapılabilmektedir. Özellikle Bartın Çayı'nın kent içi geçişinde 1998 seline kadar Kemerköprü'ye kadar sınırlı ulaşım imkânı sağlayan akarsuda bugün Asma Köprü inşaatı sonrası ulaşım sağlanamamaktadır. Akarsu ile Yalı iskelesinden Çağlayan Piknik Alanı'na kadar olan ulaşım ise diğer kola göre yatağının geniş ve suyun daha derin olması nedeniyle çok daha kolaydır.

Bartın Çayı kıyısındaki tarım alanlarında, taban suyunun yüzeye çok yakın olması önemli bir toprak kirliliğidir. Taban suyundaki yükseklik bitki kültürünü sınırlamakta ve bitki gelişimini olumsuz yönde etkilemektedir. Bu nedenle alan yakınında tarım kısmi derecede yapılmaktadır. Alan yakınında Bartın Çimento Fabrikası, Kireç Fabrikası, Orman Ürünleri Sanayi, Tuğla Fabrikası ve Belediye Mezbahası yer almaktadır. Akarsu yatağının bozulması, toz, gürültü gibi çevresel riskler bulunmaktadır.

Bartın Çayı, suyolu taşımacılığı için elverişli olması sebebiyle suya ve karaya dayalı rekreatif aktiviteler açısından önemli potansiyele sahip olmasına karşın çevresindeki yapılaşma faaliyetleri, altyapı eksiklikleri, tarımsal ve endüstriyel aktiviteler sonucunda peyzaj özelliklerini kaybetme riski ile karşı karşıya bulunmaktadır. Kentsel açık ve yeşil alan sisteminin önemli bileşenlerinden olan rekreasyon alanları Bartın Çayı boyunca sistem bütününde olmayıp, alanlar birbirinden bağımsız ve kopuk bulunmaktadır. Bartın Çayı'nın kendine has peyzaj özellikleri esas alınarak, kentsel açık ve yeşil alan sistemi bütününde değerlendirilmesi üzerinde çalışmaların eksikliği önemli bir sorundur.

Bunun dışında nehir kenarları boyunca çevrede yaşayan kırsal halkın nehri karşıdan karşıya geçmede, balıkçılık yapmada ve hobi amaçlı kullandıkları tekneler kıyı boyunca durmaktadır. Bu nehrin kullanılma isteğini gösterdiği gibi nehir tipolojisi bakımından da estetik bir görüntü oluşturmaktadır (Şekil 1a). 

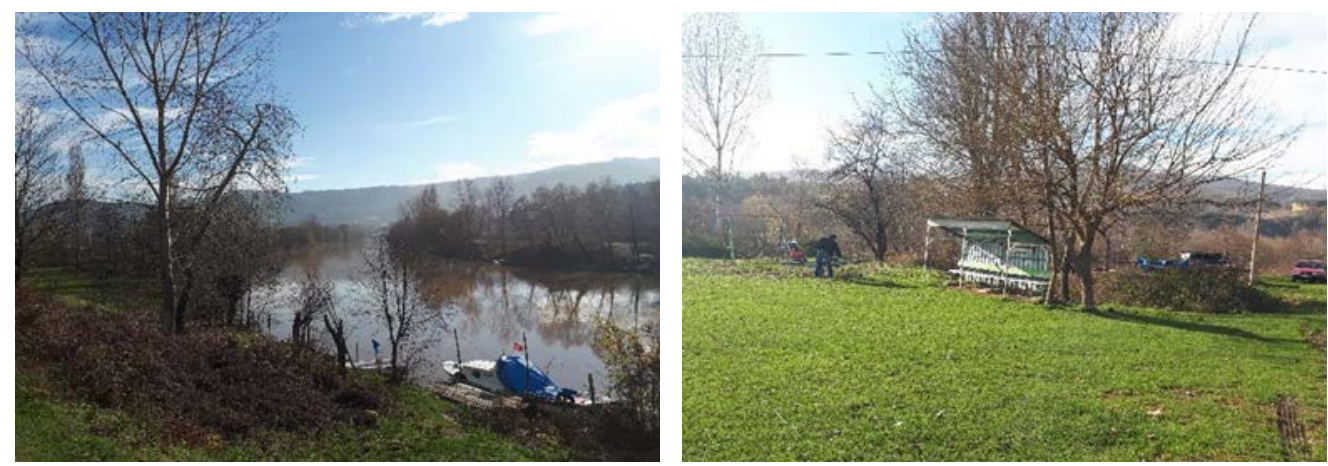

Şekil 1a. Nehir kenarında yaşayan kırsal halkın kullandığı kayıklar

Şekil 1b. Alanda bulunan rekreasyon amaçlı etkinliklere uygun açık alanlardan bir görünüm

Nehir kenarında mülkiyeti kamuya ait açık alanlar bulunmaktadır (Şekil 1b). Bu alanlarda herhangi bir çevre düzenlemesi yapılmamasına rağmen halk yaz ve kış bu alanları piknik yapmak, nehri izlemek, fotoğraf çekmek, yürüyüş yapmak vb. aktiviteler için tercih edip kullanmaktadır (Şekil 2a). Bu alanlar çalışmada tasarıma dahil edilen açık alanlar olarak önem taşımaktadır. Halkın nehir kenarında kendi olanaklarıyla yaptığı oturma birimleri ve iskeleler alanın peyzaj tasarımlarıyla yenilenip halka sunulmasının gerekliliğini kanıtlar niteliktedir (Şekil 2b).
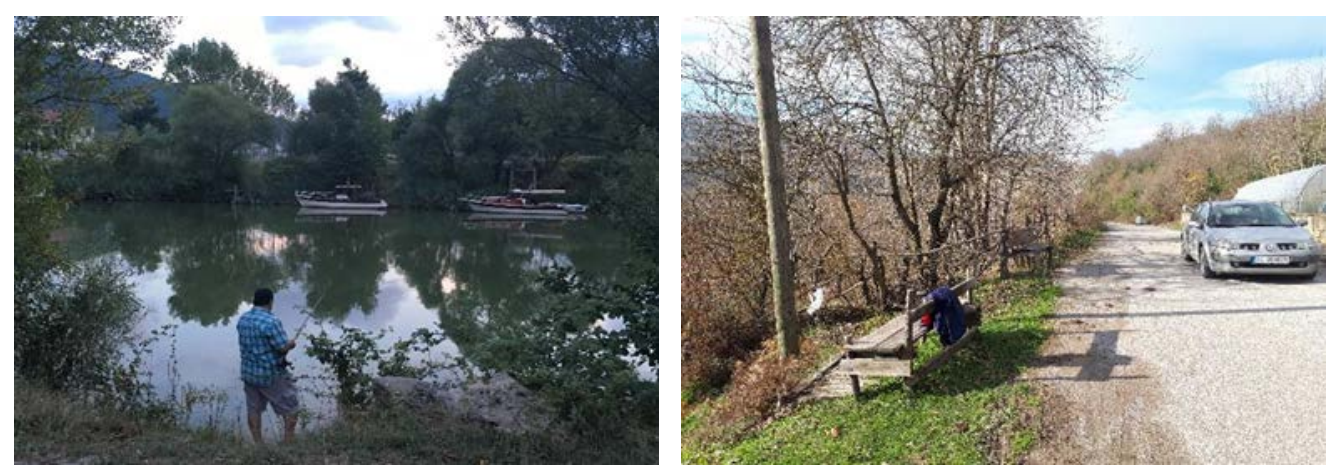

Şekil 2a. Bartın Nehri’nde olta balıkçılığı

Şekil 2b. Bartın Nehri kenarında yerli halkın kendi olanaklarıyla yaptığı oturma birimleri

Nehir kenarında bir dönem restoran ve kafeterya olarak işlev görüp daha sonra terkedilen yapılar yer almaktadır. Bu yapıların bakım ve onarımları yapılarak kullanılmaları tasarımda ihtiyaç duyulan kapalı mekân ihtiyacını karşılayabilecek ve bu şekilde proje maliyetini düşürecektir.

\subsection{Alanın Kültürel Peyzaj Özellikleri}

Bartın Kenti adını antik çağda Parthenios'dan (Sular ilahı) almıştır. Kentin ismine ilham veren Bartın Çayı mitolojik öneme sahiptir. Bartın Kenti ve yakın çevresinde ilk yerleşmeler, M.Ö 14. yüzyılda kurulmuştur (Anonim, 2001). Bartın, Zonguldak İli’ne bağlı ilçe konumundayken 1991 
tarihinde il statüsüne kavuşmuştur (Anonim, 2001). TUİK verilerine göre Bartın’ın nüfusu 2018 y1lı sayımına göre 198.999 'dir. Bu nüfus, 98.913 erkek ve 100.086 kadından oluşmaktadır. Nüfusun \%49.71'i erkek, \%50.29'i kadındır.

Tarihsel süreçte Bartın Kenti ve çevresindeki ticaretin canlı olmasında Bartın Çayı önemli rol üstlenmiştir. Bartın Çayı aracılığıyla çeşitli mallar diğer limanlara pazarlanmıştır. Bu nedenle, MÖ. 11-10. yüzyıllarda Fenikeliler, sonra da Kayralı ve Megaralı gemici tacirler tarafından Bartın Çayı bilinmektedir. Evliya Çelebi Seyahatnamesinde "Bartın Çayı azim bir nehirdir, Buğday-mısır gemileri yükleyip giderler” şeklinde ifadeler yer almaktadır (Erkin, 1978). Bartın'da gemi yapımcılığının geçmişi, yaklaşık 400 yıl öncesine dayanmaktadır. Bartın'da 1950 yıllarına kadar varlıklarını sürdürdükleri bilinmektedir (Anonim, 2005).

Bartın Çayı, suyolu taşımacılığına elverişli olmasının yanısıra, kent halkının çeşitli rekreatif ihtiyaçlarına yönelik önemli bir potansiyel niteliği de taşımaktadır. Ancak, çevresinde bugüne kadar birkaç park ve piknik alanı dışında rekreasyonel amaçlı herhangi bir tesis yapılmamıştır. Kocaçay kıyısında; Çağlayan Mevkii'nde kentin önemli piknik alanlarından olan Çağlayan Piknik Alanı yer almaktadır. Orduyeri Köprüsü ile Gazhane Mevkii arasındaki kıyı şeridinde yer alan Yalı Boyu Dinlenme Alanı bulunmaktadır. Kocanazçayı kıyısında; Kemerköprü Mahallesi’nde anıt ağaçların Platanus orientalis L. (Doğu çınarı) bulunduğu Belediye Sosyal Tesisleri Bahçesi, Bartın Çayı kıyısında (Kocaçay ve Kocanazçayı'nın birleşme noktası olan Gazhane Mevkii’nde); Gazhane Parkı, Karaçay Deresi kıyısında piknik alanı bu alanları oluşturmakta ve halk tarafından yoğun olarak kullanılmaktadır (Yılmaz ve Cengiz, 2003).

\section{3 Çalışma Alanı Peyzaj Tasarım Projesi}

Bu bölüme kadar incelenen yurt içi ve dışı örnekler, alanda yapılan gözlem ve değerlendirmeler sonrasında Bartın Nehri Gölbucağı-Boğaz kesimi için alanın doğal ve kültürel yapısı ve kaynak değerlerine uygun bir proje üretilmiştir. Peyzaj düzenlemesinde ana plan kararları;

$\square$ Nehir yatağı boyunca sürekli mekân anlayışıyla yeşil alanlar oluşturmak,

$\square$ Kentsel peyzajı doğal yapıya kademeli olarak dönüştürmek,

$\square$ Kırsal peyzaj alanlarını ve kültürü korumak,

$\square$ Ekolojik parklar, şelaleler ve fiskiyeler gibi suya dayalı tematik alanlar oluşturmak,

$\square$ Yaya yolu ve bisiklet sirkülasyonu ile hareketi öngören sağlıklı yaşam alanları oluşturmak,

$\square$ Âtıl durumda bulunan alanları geri kazanmak,

$\square$ Kent içinde ve İnkum'da yer alan ancak bu iki yerleşim arasında kopan kentin turizmrekreasyon ağını birleştirmek,

$\square$ Nehir habitatını, balık ve vahşi yaşamı korumak ve değerini arttırmak, 
$\square$ Rekreasyonel ve açık alan kullanım imkânı sağlamak ve bu şekilde kaliteli yaşam alanları oluşturmaktır.

Projenin hedefi, harap durumda olan alanları ile mevcut durumdaki boş açık alanları geliştirmek ve halkın aktif kullanabileceği bir rekreasyon alanına dönüştürmektir. Çalışma alanında mevcut durumda bulunan açık alanların yeşil alan sisteminde peyzaj tasarımlarının yapılması bu alanların doğaya kazandırılması nitelik ve nicelik bakımından yeşil alan miktarının ve dolayısıyla kentsel yeşil alan ve kişi başına düşen yeşil alan oranlarının yükseltilmesi bakımından önem taşımaktadır. Çünkü nehir koridorları ekolojik koridor olarak doğanın en değerli kaynak değerlerinden biridir. Nehir kıyılarının doğaya uyum sağlamayan başka kullanımlarla çevrelenmesi bu yapının bozulması anlamına gelecektir. Doğaya ve nehir ekosistemine en uygun kullanımlar olarak bu alanların açık yeşil alan sistemine dahil edilmesi en uygun tercih olacaktır. Bu kapsamda çalışma alanı kapsamına giren Bartın Nehri kesimi ve üzerinde tasarlanması düşünülen kullanımlar proje ve üç boyutlu görseller şeklinde sunulmuştur (Şekil 3) (Çizelge 1).

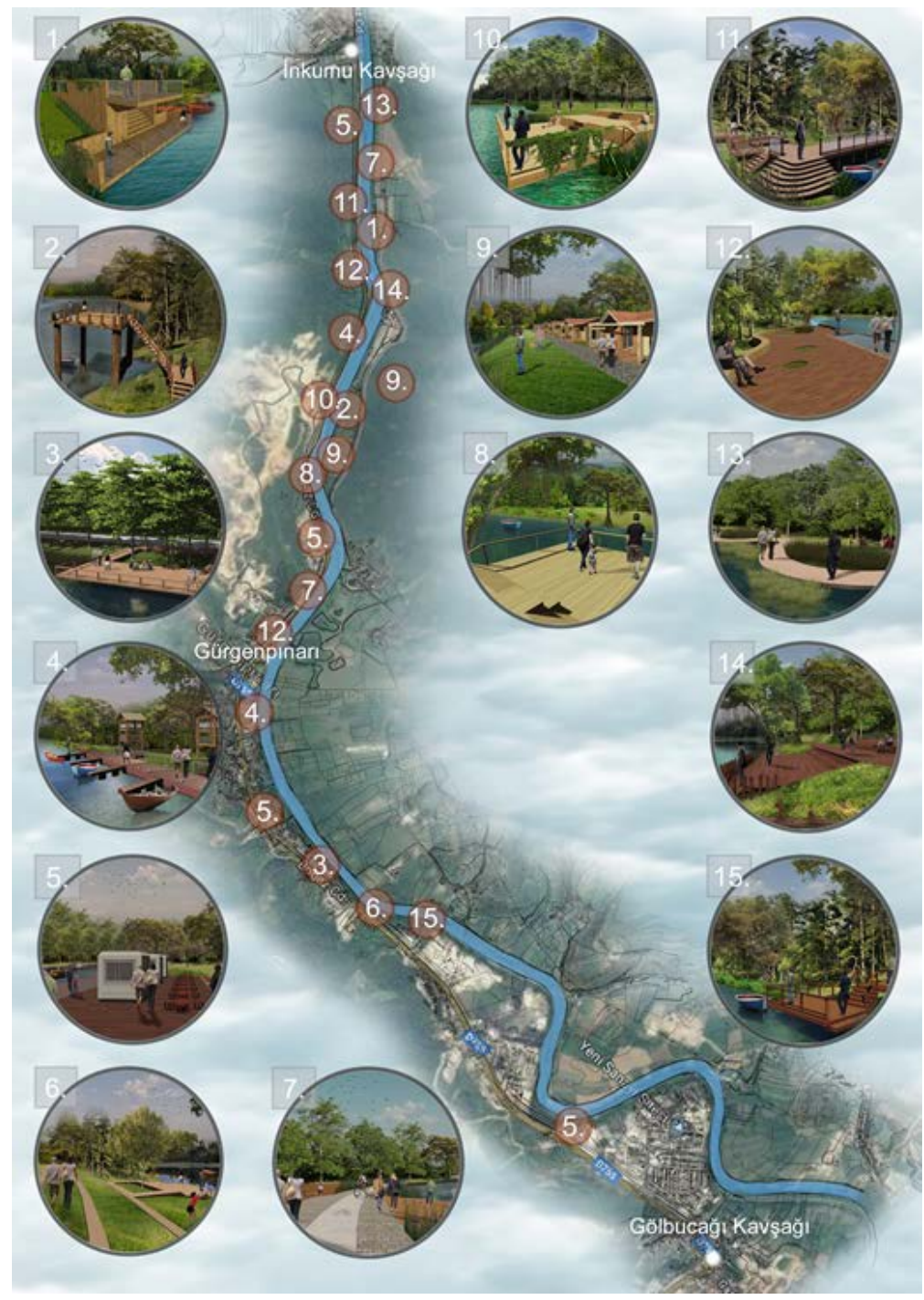

Şekil 3. Çalışma alanı peyzaj tasarım projesi 
Çizelge 1. Çalışma alanı peyzaj tasarım projesi plan ve görünüşleri

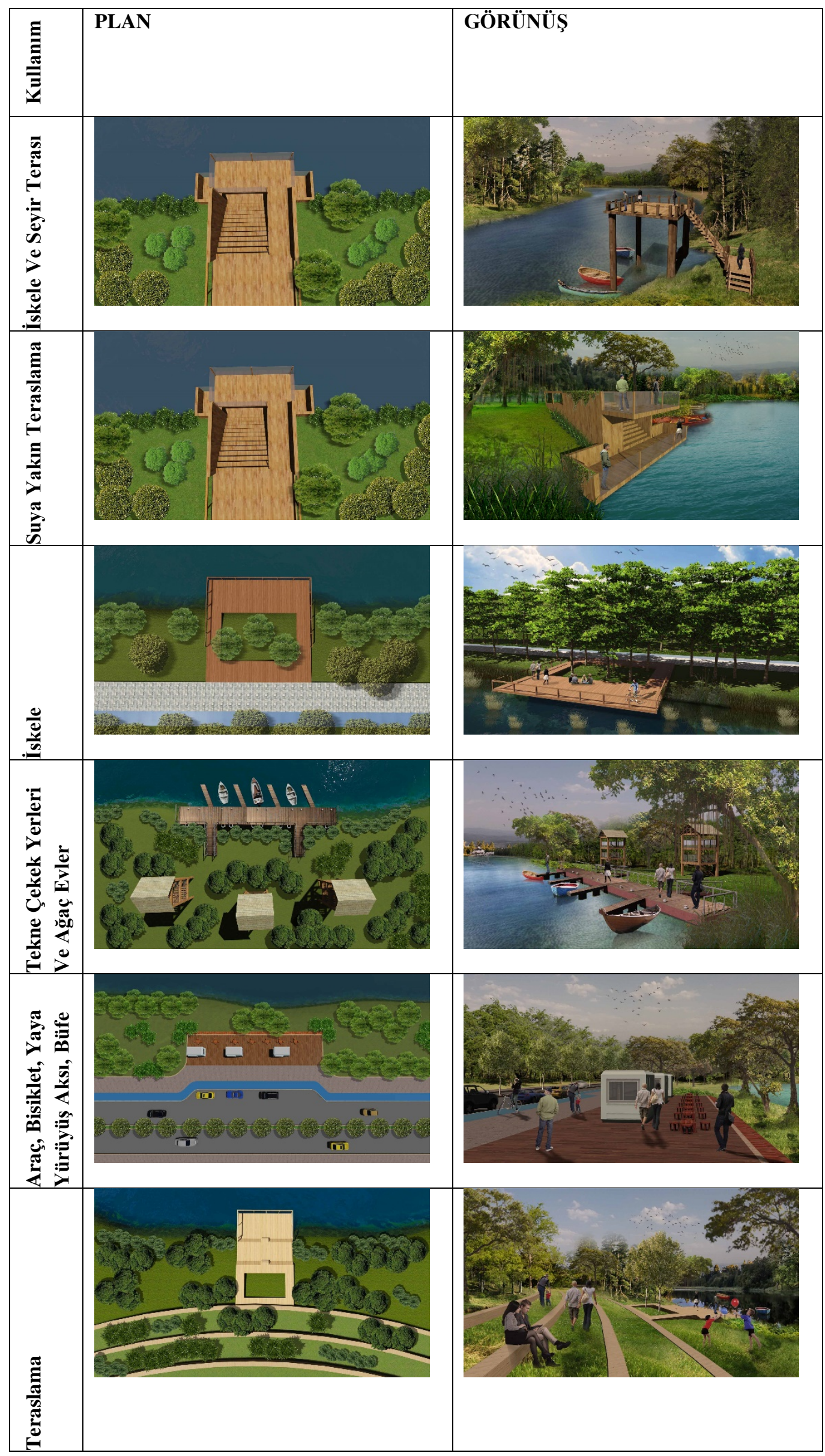




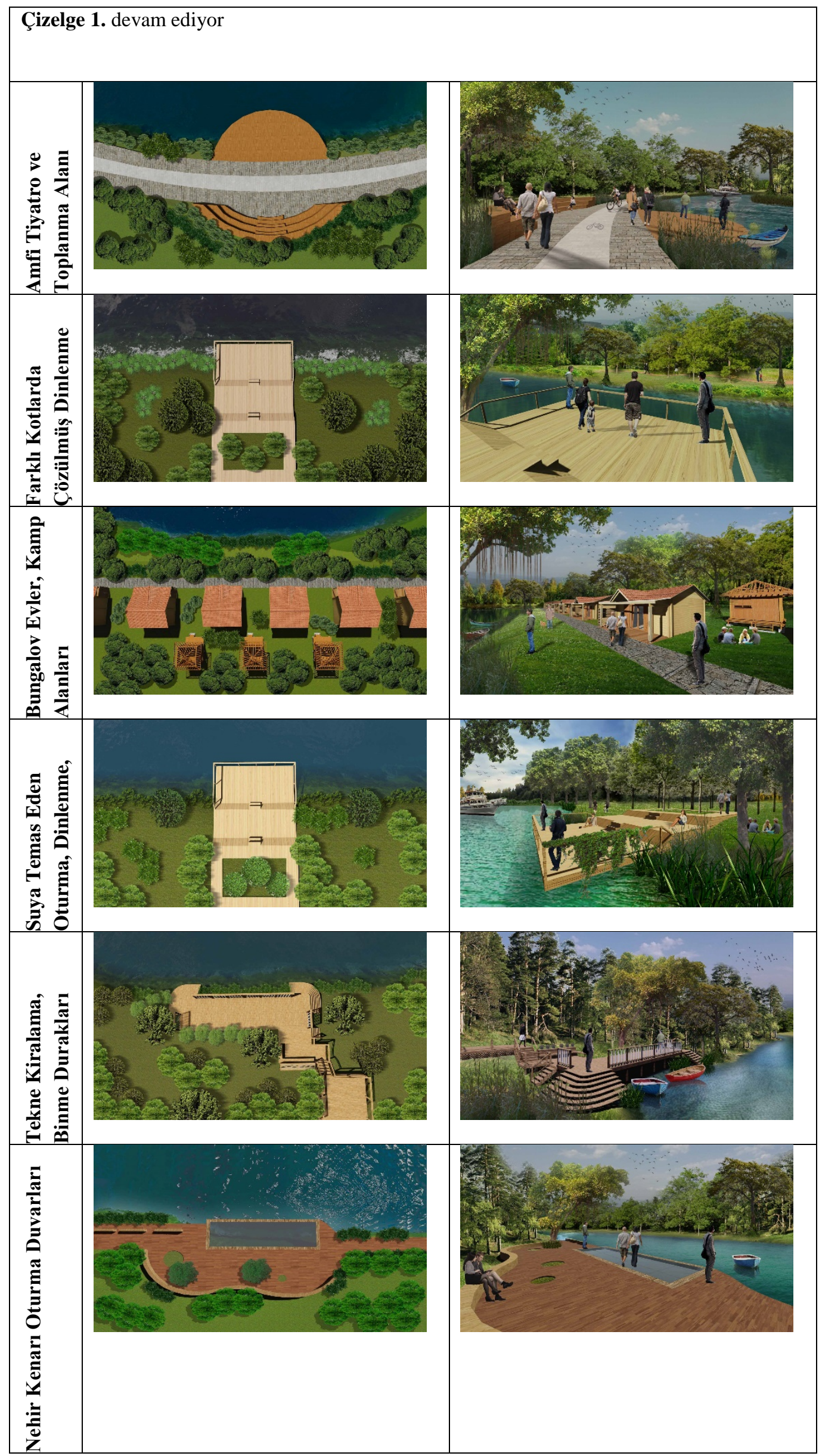




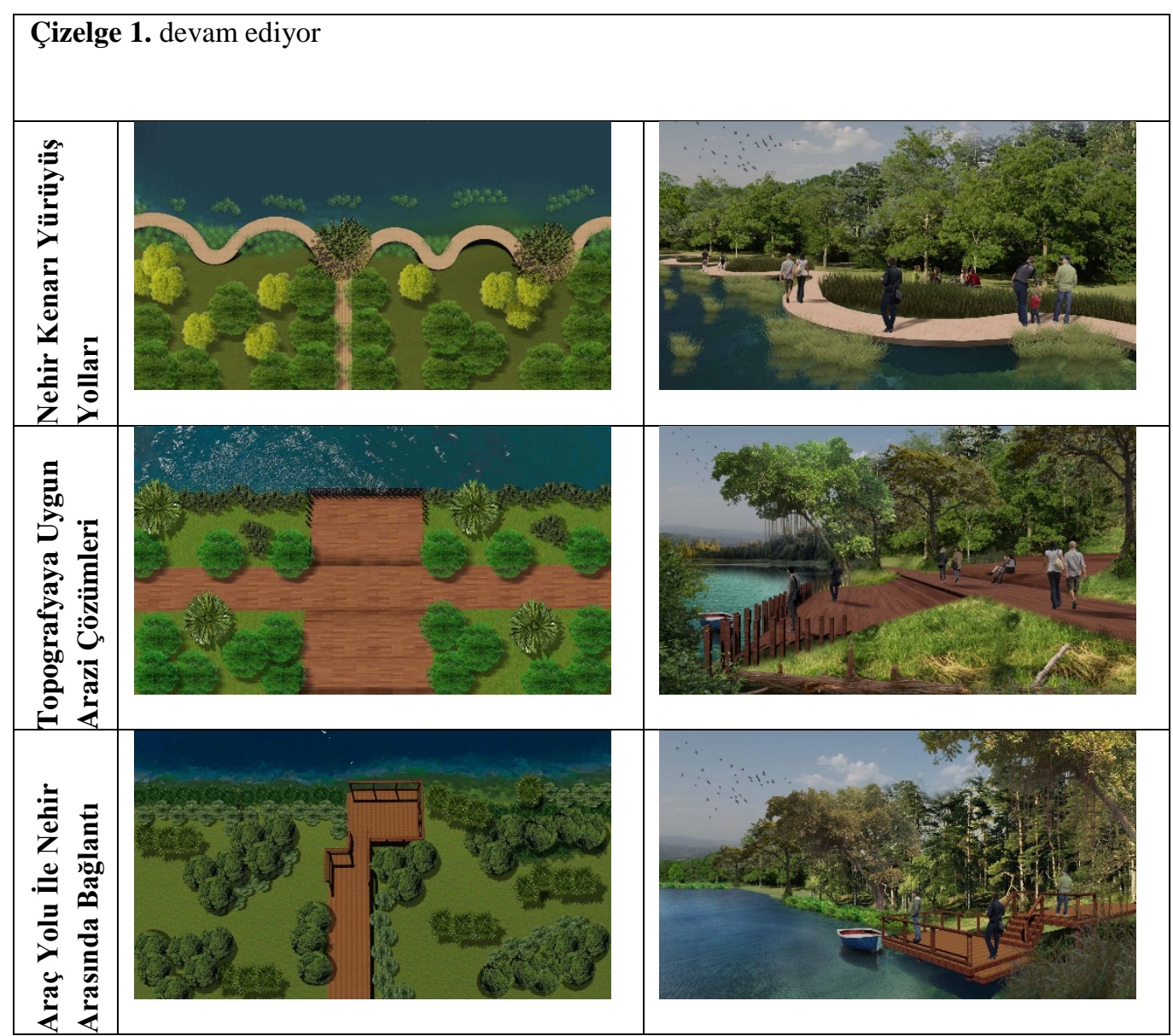

\section{Sonuçlar ve Öneriler}

Bartın Nehri rekreasyonel aktivitelerin yapılabilmesine uygun bir potansiyele sahiptir. Proje ile kent içinde halka alternatif bir rekreasyon alanı oluşturulması kentin imajı açısından da önemli olacaktır. Çünkü nehir ve su kaynakları bakımından dünyanın birçok ülkesine göre avantajlı olmamıza rağmen, kıyı koruma ve geliştirme projeleri bakımından yeterli uygulamaları yapabildiğimiz söylenememektedir. Çalışma sonunda yapılması düşünülen tasarımla nehrin kent için önemi ve rekreasyonel kullanımı bakımından çekiciliği artacak, düzenlenecek yeni alan toplumsal çekim alanı olacak ve her kesimden halka hitap edecektir. Projeyle mevcut durumda âtıl olan ve potansiyeli değerlendirilmeyen alan mekânsal kullanım, kullanıcı isteği ve ekolojik iyileştirmeler bakımından yarar sağlayacaktır.

Bartın Kenti deniz kıyısına 17 km yakınlıkta olan bir kent olmasına rağmen kent merkezinin deniz kenarında kurulmaması merkezde yaşayan insanların günün farklı saatlerinde ve kısa süreli kıyıya ve suya ulaşma istemini denizlerden değil nehir kenarlarından karşılamak yönünde bir isteme dönüştürmüştür. Mevcut durumda kenarı düzenlenmeyen nehir kenarı alanlarında bile halk bu alanlardan kendi çabalarıyla yararlanmanın çözümünü bulmaktadır. Köprüler üstünden balık tutma, 
sandallarla ve şişme botlarla suya açılma, arabalarla gezi ve genişlemelerin olduğu yerlerde piknik yapma gibi eylemler bunun başlıca göstergesidir.

Düşünülen tasarım projesi sonrası halkın boş zamanlarını değerlendirdiği, görsel açıdan zengin fonksiyonları açısından yararlı tasarıma sahip, ekolojik çevrenin korunup geliştirildiği örnek bir alan yaratılmış olacak ve yeni alan kentin sembolü durumuna gelecektir.

\section{Teșekkür}

Bu çalışma Bartın Üniversitesi Bilimsel Araştırma Projeleri Koordinasyon Birimi tarafından “2018-FEN-CY-001” kodlu proje ile desteklenmiştir.

\section{Kaynaklar}

Anonim, (1995). Bartın ve Turizm. İl Turizm Müdürlüğ̈̈ Yayınları No: 2, Bartın.

Anonim, (1998). Cumhuriyetimizin 75. Yılında Bartın. İl Özel İdare Müdürlüğü, Bartın.

Anonim, (2001). Bartın Koruma Amaçlı İmar Planı Araştırma Raporu. Ege Plan Şti. yayını, Ankara.

Anonim, (2005). 2004 Yılı Bartın İli Çevre Durum Raporu. Bartın Valiliği İl Çevre Müdürlüğü yayını, Bartın.

Anonim, (2006). Zonguldak, Bartın, Karabük Planlama Bölgesi 1:100000 Ölçekli Çevre Düzeni Planı Araştırma Raporu. JEO-TEK and UTTA Ltd. İs. Ortaklığı, Ankara.

An, A., (1994). Eskişehir Porsuk Çayı Çevre Düzenlemesi Üzerine Bir Çalışma, AÜ Fen Bilimleri Enstitüsü, Yüksek Lisans Tezi (Basılmamış).

Arslan M, Barış E, Erdoğan E, Dilaver Z, 2005. Korunan Alanlarda Yeşil Yol Planlama Örnekleri, Korunan Doğal Alanlar Sempozyumu, Isparta.

Berberoglu, U., (2004). Haliç Kıyılarındaki Yeni Düzenlemeler ve Kıyı Parklarının Kullanıcılar Tarafından Değerlendirilmesi, İTÜ. Fen Bilimleri Enstitüsü, Yüksek Lisans Tezi (Basılmamış).

Demirca, A., (1999). Bartın Çayı Ağzı-Amasra-Çakraz Koyu Arasının Kıyı Jeomorfolojisi. Yüksek İstanbul Üniversitesi Sosyal Bilimler Enstitüsü Yüksek Lisans Tezi (Basılmamış).

Erkin, E., (1978). Bartın (Zonguldak) Analitik Etütler. İller Bankası Genel Müdürlügü, Ankara.

Fairbrother, N., (1976). The Natural of Landscape Design. The Architectural Press, London.

Hattapoğlu, Z., (2004). Su Olgusunun Yerleşmeler Evrimindeki Yeri ve Günümüzde Bir Kentsel Tasarım Elemanı Olarak Yeniden Yorumlanması, MSÜ. Fen Bilimleri Enstitüsü, Yüksek Lisans Tezi (Basılmamış).

Kılıçaslan, Ç., (2004). Akarsuların Kentsel Gelişme-Dönüşüm Süreci İçinde Çeşitli Kullanımlar Yönünden Etkileşimlerinin İzmir Kenti Örneğinde Ortaya Konulması, EÜ Fen Bilimleri Enstitüsü, Doktora Tezi (Basılmamış).

Musayev, E., (2003). Kentsel Kıyı Dolgu Alanları Kullanımı Çerçevesinde Yalova 17 Ağustos Kıyı Parkının Peyzaj Planlama ve Tasarım Açısından Irdelenmesi, İTÜ. Fen Bilimleri Enstitüsü, Yüksek Lisans Tezi (Basılmamış).

Önen, M., (2006). Kentsel Kiyı Mekanı Olarak Akarsuların Rekreasyonel Kullanım Potansiyelinin Irdelenmesi: Eskişehir Porsuk Çayı ve İstanbul Kurbağalı Dere Örneği, İTÜ. Fen Bilimleri Enstitüsü, Yüksek Lisans Tezi, (Basılmamış).

Simsonds, J. O, (1994). Garden Cities 21, Creating Livable Urban Environment, Fasla, 554.

Şengül, E., (1995). Mimari-Su İlişkisi Üzerine Bir İnceleme, İTÜ. Fen Bilimleri Enstitüsü, Yüksek Lisans Tezi (Basılmamış).

Şişman, E., E. ve Yetim, L., (2004). Tekirdağ Kentinde Donatı Elemanlarının Peyzaj Mimarlığı Açısından İrdelenmesi, Trakya Üniversitesi Fen Bilimleri Dergisi, 5 (1):35-41.

Turoğlu, H. Ve Özdemir, H., (2005). Bartın'da Sel ve Taşkınlar Sebepler, Etkiler, Önleme ve Zarar Azaltma Önerileri. Çantay Yayınevi, İstanbul. Tzolova. 
Uzun, T., (2001). Kıyı Bölgelerinde Arazi Planlaması, YTÜ. Fen Bilimleri Enstitüsü, Yüksek Lisans Tezi (Basılmamış).

Yılmaz, H., (2001). Bartın Kenti ve Yakın Çevresi Biyotoplarının Haritalanması. İstanbul Üniversitesi Fen Bilimleri Enstitüsü Doktora Tezi (Basılmamış).

Yılmaz, B. ve Cengiz, B., (2003). Turizm ve Rekreasyon Potansiyeli Bağlamında Bartın Çayı ve Yakın Çevresi Peyzaj Değerlerinin Koruma Öncelikli İrdelenmesi. Coğrafi Çevre Koruma ve Turizm Sempozyumu, Sayfa: 159-168, İzmir. 